\title{
Case Study of Children Living with Disabilities in Ekiti State, Nigeria: A Look at Their Information Access and Social Inclusion
}

\author{
Ogba Chidinma Onwuchekwa ${ }^{1}$, Adetifa Emmanuel Kayode ${ }^{2}$ \\ ${ }^{1}$ Lecturer and Law Librarian, Ekiti State University, Ado-Ekiti, Ekiti State, Nigeria \\ ${ }^{2}$ Lecturer, Faculty of Law, Ekiti State University, Ado-Ekiti, Ekiti State, Nigeria \\ Email: *chidinma.ogba@gmail.com, adetifakay@gmail.com
}

How to cite this paper: Onwuchekwa, O. C., \& Kayode, A. E. (2021). Case Study of Children Living with Disabilities in Ekiti State, Nigeria: A Look at Their Information Access and Social Inclusion. Beijing Law Review, 12, 794-812.

https://doi.org/10.4236/blr.2021.123042

Received: July 2, 2021

Accepted: August 15, 2021

Published: August 18, 2021

Copyright $\odot 2021$ by author(s) and Scientific Research Publishing Inc. This work is licensed under the Creative Commons Attribution International License (CC BY 4.0).

http://creativecommons.org/licenses/by/4.0/

\begin{abstract}
Nigerian children who are disabled are dependent on special materials in order to be able to access information and get socially included. However these materials are costly and out of their reach. This study therefore investigated how children living with disabilities in Ekiti State, Nigeria access academic information and get socially included. Social model of disability theory was used to guide the study. Case study design was used for the study. The population was made up of 40 teachers of disabled children that gathered for a conference. A self-designed structured interview was used to gather data. Due to the small population of the teachers, they were all used for the survey. The statements of the respondents were assigned codes that focused on the key concepts of the study. Constant comparative method of data analysis was applied to compare and contrast codes; while data connections were made paying attention to categories of data and concepts. This continued until saturation was made, then evidences of research were selected and tabulated. Findings showed that there were shortage of materials that would provide information access and there was no social inclusion. They were also not receiving love and good treatment at their homes. The study concluded that information access and social inclusion of children living with disabilities in Ekiti State, Nigeria is limited. Recommendations involving the Ministry of Education and human rights groups were made.
\end{abstract}

\section{Keywords}

Child Rights Law, Children Living with Disabilities, People with Disability, Information Access, Human Rights, Social Inclusion 


\section{Introduction}

Disability is a limitation with the potential to inhibit the exercise of human rights; especially rights that require self-dependence for enjoyment. The right to information expression would be meaningless to a speech impaired disabled except where there is communication tool for assistance. In the same way, a right to life would not be enjoyed by a disabled who cannot access health information and health facilities. Right to association as also contained in Nigerian constitution would be meaningless if a physically disabled person is not provided with tools that will assist mobility and enable them to interact socially. According to Manzoor and Vimarlund (2018), disability limits one's ability to access health facilities, apply personal hygiene, associate in its totality and has the tendency to expose a disabled person to constant denial of dignity due to possible dependence on human aid for assistance. A disabled person does not have the liberty of self-service where he or she is not enabled through disability aids (Rabinowitz, 2020). According to Abang (2007), the Nigerian society has a negative attitude towards the disabled due to myths and superstitions assumed to be associated with being disabled. More so, there has not been much consciousness, despite much awareness, on the disabled as to warrant their inclusion in plans relating to education, health facilities and personnel, public facilities and tertiary institution; in so much that they are actually included as part of the society (Rabinowitz, 2020; World Health Organization, 2020). They are placed as subjects of continuous planning (Rabinowitz, 2020) and problems constantly requiring solution (Benstead, 2019); thus raising concern on whether the disabled are accessing information and getting included in the society.

This paper uses a social model of disability theory (SCOPE, 2021) to guide the study. Social model of disability theory states that the disabled are not impaired as they have the ability to move, hear and bridge their limitations if they are provided with the tools and mechanism to do so. Thus where a disabled is limited and is not able to do anything on his own, such is not his disability but that of the society or organization that was not able to provide what was necessary for the disabled mobility. This means that the disabled have the ability to access information and be socially included as long as they are provided with tools and an enabling environment to do so. Thus in looking at the ability of the disabled to access information and be socially included, focus is on whether they have the right tools to access information and be socially included.

Disability is defined in this paper as limitations in physical or sensory parts of the body in relation to moving, seeing, hearing, understanding, and having positive skin sensitivity including every other limitation that makes a person incapable of responding completely to his or her environment without external or internal aid. World Health Organization (WHO) (2019) defined disability as an umbrella term of all impairments, activity limitations and participation restrictions; and as such not a disease but a complex phenomenon that concerns the interaction between a disabled person and his or her external environment. In- 
stances of internal impairment are where a child has brain disability, cognitive disability, and speech disorder; while external impairment is where the disability could be seen with natural eyes (Ajanwachuku \& Philip, 2018). These categories of impairment have in common, a dependence on tools for ability to live; tools that are costly and mostly out of the reach of the poor (Mitra \& Groce, 2017).

According to documented information in Nigeria, the majority of Nigerian population are living below average (Kazeem, 2018) and thus are not able to acquire disability tools they require for information access and social inclusion. Hence the tendency to depend on the government for provision of essential materials needed for their living. However this dependence and responsibility placed on Nigerian government was placed as a non-justiciable provision that cannot be an issue in a court of law (Discrimination against Persons with Disabilities (Prohibition) Act, 2018; Nigerian Child Rights Act, 2003). Thus warranting the inability for complete enjoyment of disability rights of the disabled; which rights include the provision of tools and amenities required for the full enjoyment of their human rights. Arimoro (2019) concludes that Nigerian government has been unable to implement fully, measures needed to make live easy for the disabled. In response to disability needs and the plight of majority of disabled Nigerian population, the Convention on the Rights of Children (CRC) (International Justice Resource Center, 2019), African Charter on the Rights and Welfare of the Child (ACRWC) (UNICEF, 2019), Nigerian Child Rights Act (2003), Discrimination against Persons with Disabilities (Prohibition) Act (2018) mandate government of each country to provide for materials and amenities that ease the lives of the disabled. Such mandates being made subject to the sovereign power of states to domesticate and execute.

A child is defined in UNICEF (2019) as anybody who is 12 years or below. However African Charter on the Rights and Welfare of the Child (ACRWC) defined a child as any human being below the age of 18 years (Art.2 ACRWC). Article 23(1) of CRC defined a disabled child as one who is mentally or physically impaired (Ajanwachuku \& Philip, 2018). Article 11 of ACRWC in making an all-inclusive provision stated that every child has a right to education and a right to develop his or her personality, talents, mental and physical abilities to their fullest potential. An addendum was included in this provision, which is that government of each country should take special measures to protect amongst all, disabled children and ensure equal access to education for all sections of the community. This provision apart from been domesticated in Nigerian Discrimination against Persons with Disabilities (Prohibition) Act, 2018; has also been replicated in Discrimination against Persons with Disabilities (Prohibition) Law (2020), Ministry of Justice Ekiti State (2020) and other states laws. Some of the provisions of the Discrimination against Persons with Disabilities (Prohibition) Law, 2020 are the duty to provide support (S.8), the right to life and personal liberty (S.9), the right to live in the community (S.10), freedom of speech (S.17); and of much importance are sections 20 and 21 which provides for the 
duty of the government to provide for inclusive education. Inclusive education is an education where they are socially included in main stream schools; and also where they are provided with needed materials for their education and information access.

Information access is defined in Encyclopedia (2020) as the ability to identify, retrieve and use information effectively. Thus information access is a combination of sense organs, physical or mobility limbs and information skills. Disability then becomes a major limitation to information access except when there is enabled ability to access needed information. In Buckland (1991), access was defined as an "enabler"; enabler to learning, development, knowledge building and social inclusiveness. Information access was thus seen as a basis for total wellbeing in the society; a human right. Lloyd, Lipu and Kennan (2017) conclude that ability to identify materials and availability of such materials, including the cost of such availability and the cognitive ability to access such materials are barriers to accessing information. By extension, they are also barriers to social inclusion since social inclusion thrives on access to information.

Social inclusion has been defined as the process of improving the terms or modalities in which individuals or groups take part in the society (World Bank, 2020). It was further defined by World Bank (2020) as the process of improving the ability and opportunity of people who are disadvantaged due to their identity; in order for them to participate in the society in which they live. Such modalities and terms enhance their disability in such a way that they can live and interact freely in the society on their own. According to Lloyd, Lipu and Kennan (2017), "ability" is the primary factor to social inclusion in the society. For secondary school children from poor homes, equipping them with ability is providing them first with the body materials needed to enhance their disability; then the provision of specific educational materials needed for learning, information access and mobility. This sums up the second definition of social inclusion by World Bank (2020), which is adopted for definition of social inclusion in this study.

Children living with disabilities require access to academic information and need to interact with their peers in order to academically engage and exercise equal rights with other children. However their ability to gain information and interact depends on provision of special materials required to enhance their disability. This becomes an issue in a country where the majority of its citizens are poor and unable to provide disability tools needed for access. Although there are legal provisions that require the government of Nigeria to make adequate provisions that would enable equal access and inclusion of the disable; however the same law provides a clause which makes it not legally mandatory for the government to do so. It then becomes an issue on how disabled children in Nigeria are able to exercise access to information and be socially included. It is in line with this that this study is carried out to investigate the information access and social inclusion of children living with disabilities in Ekiti State, Nigeria. It will 
specifically seek to find out the ability of disabled children in accessing information required for their education; the challenges they have in accessing information required for their education and the extent of their social inclusion.

\section{Literature Review}

Children with disabilities fit in as disadvantaged ones under Convention on the Elimination of All Forms of Discrimination against Women (1971) (Arts 10 \& 16), Universal Declaration on Human Rights (1948) (Art 25(2) and Article 11 of African Charter on the Rights and Welfare of the Child (ACRWC, 1990). This charter has made provisions for the information access of children living with disability. Articles 12 and 13 made provisions for their social inclusion by providing that they have a right to play and participate fully in cultural and artistic life (UNICEF, 2019) while Article 13 states that they have a right to special protection, dignity, promotion of their self-reliance and active participation in the community. The provisions of ACRWC were domesticated in Nigerian Child Rights Act, 2003 and Discrimination against Persons with Disabilities (Prohibition) Law, 2020 to the extent that the provision mandates government to provide and make available resources needed for their inclusiveness and education; although with an addition not provided in ACRWC, which addition states that such mandate on governors is non-justiciable, meaning that governors would not be answerable in court of law with regards to the implementation of disability law provisions. The non-justiciable provision is not included as an objective in this paper and so will not be fully discussed within. Despite this, it is noted that the social inclusion of children and their ability to participate and interact on their own, with no external human help was included in the African charter and seen as a contributory factor for their total wellbeing and exercise of human right (Furrer \& Skinner, 2003); self-dignity is a fundamental human right provision that includes the disabled in Nigeria (Nigerian Constitution, 1999: Chap. IV).

According to Furrer and Skinner (2003), the collaboration and interaction disabled children get from their able peers assist them in their academic engagement. Despite this, it has been shown that much focus has not been directed towards investigating their social inclusion or information access (Community Tool Box, 2019; Kaeding, Velasquez, \& Price, 2017); as such there has been insufficient document that speaks for their situation. Although Small, Myhill and Herring-Harrington (2015) found that there is insufficient funds and time to cater for the needs of children living with disabilities; reiterating the conclusion in Kaeding, Velasquez and Price (2017) which states that much attention has not been given to issues relating to children living with disabilities. However Hayes (2017) found that one out of three children does not attend school because their families who are ashamed of them deny them access to education and social inclusion. In Hayes (2017), there is free education, but families' prestige becomes an issue; thereby making families of disabled children a factor to their information access and social inclusion. Social inclusion has been an issue of concern as 
many studies carried outside Nigeria show that children with disability have difficulty getting socially included. This is because of the difficulty in including them in mainstream school; as a result, they are placed in separate schools and world of their own (Arimoro, 2019).

World Bank (2019) in defining social inclusion stated that it is a continuous process of ensuring that there are provisions of good terms to include individuals and groups, especially the vulnerable and the disadvantaged, in the activities taking place in the society just like every other person. Thus, social inclusion becomes an exercise of right to life and other fundamental human rights. According to Koller, Pouesard and Rummens (2017) and World Bank (2019), disabled children globally are being left out of social inclusion in society as it relates to global efforts to improve education, with the majority of them being unable to complete their primary education. Although this report is not a reflection of states in Nigeria, it raises the question on the inclusiveness of children living with disabilities as it relates to their education in school and society. With scarcity of documents showing the situation of the disabled in Nigeria, one would not be able to state their situation except that Arimoro (2019) recommended for special training to be given to teachers on education of disabled children, so that they can always be included in regular schools while Adetoro (2014) stated the need for inclusive education for the disabled. This is because from observation and based on the authority of Arimoro (2019) and Adetoro (2014), disable children in Nigeria are placed in special schools away from the able children. Thus they are rarely given the privilege of relating with other children who are in regular schools.

In order to provide a solution to exclusion and inclusiveness, Tuersley-Dixon and Frederickson (2016) stated that the practice was to include disabled children in mainstream schools so that they would learn to interact with able children. Although Avramidis as cited in Benstead (2019), and Koller, Pouesard and Rummens (2017) found that children with disabilities suffer from bullying, loneliness and exclusion with the tendency to suffer psychologically; making them always in need of counseling. However Tuersley-Dixon and Frederickson (2016) also found that children who were included in mainstream schools were found to be accepted just because they were visible; thus their acceptance had nothing to do with their disability but with their visibility. Thus visibility enhances acceptability of disabled children by able children and in turn encourages relationships and social wellbeing. This reiterates the conclusion in Furrer and Skinner (2003) that the collaboration and interaction disabled children get from their able peers assist them in their academic engagement while the love they get from their homes provides a stronger support. Since many states in Nigeria do not have disabled children in mainstream schools, it would be difficult to know the level of their acceptance and social inclusion among able children.

The conclusion in Tuersley-Dixon and Frederickson (2016) that disabled children were accepted in mainstream schools because they were visible, al- 
though different from the finding in World Bank (2019) which states that disabled children are globally left out of social inclusion, however portrays that environment and visibility could determine the reaction of able children towards the disabled children. Where the disabled children are kept aside and hidden from able children, a social barricade is provided which makes them seem different and unapproachable; and raises the assumption that they will not be accepted. In relation to this, Adetoro (2014) stated the need to practice inclusive education in Nigeria while European Disability Forum (2016) stated the need for civil societies to monitor the social inclusion of disabled children, with the aim of ensuring that their human rights are adequately protected.

United States National Library of Medicine (Definitions.Net, 2019) defined information access as "individual's rights to obtain and use information collected or generated by others". It is the ability to access and obtain information in any form for any purpose. Thus for the disabled, their right to information access is attached to their ability to access. This means that where they are not enabled to access information, their human right to information expression is automatically denied. It could as well be argued that where their right to information expression is denied, then the government who is mandated to provide access becomes responsible; although they cannot be questioned in court of law (Ajanwachukwu \& Philip, 2018). However Access to information is an attendant right to fair hearing, the right to health is an attendant right to life and the right to education is an attendant right to information expression, and every of these rights are attached to fundamental rights provisions in Nigerian constitution especially the rights to non-discrimination, dignity of person and right to association (Nigerian Constitution, 1999: Chap. IV). According to Ajanwachukwu and Philip (2018), they are basis for litigation in courts of law; except for the inclusion of non-justiciable provision in Nigerian disability law.

Kaeding, Velasquez and Price (2017) assert that there is limited literature with focus on information access of children living with disability. Though the focus of Kaeding, Velasquez and Price study was on access to the library; however within the period of the study, it was found that there was limited documentation on children living with disability with regards to what they need for easy access to information. This conclusion was confirmed in Small, Myhill and Herring-Harrington (2015). In Small, Myhill and Herring-Harrington (2015), it was shown that there was need for sufficient finance and provision of time amongst others, in order to provide for their needs. Thus it has been documented what their needs are; just that provision was not forthcoming and attention was not being given to them. This aligns with the statements in Community Tool Box (2019) that the needs of people living with disabilities were not been considered in designing features of buildings. Thus, their inability to access buildings where they would access information inhibits their ability to access required information; a confirmation to the social model of disability theory which states that where ability tools are not provided to disabled people, then they should not be 
referred to as disabled for it is the society and government that has made their ability to be disability.

Hayes (2017) discovered that one out of three children does not attend school because their family in trying to avoid embarrassment and shame deny them access to education. Solution to this was however provided when international non-governmental organizations like UNICEF in partnership with USAID and CLED (Campaign for learning disability) embarked on sensitization program for families and communities. Sensitization then became the solution applied in providing access to education that was denied by family of the disabled due to shame. This means that there is always a need to embark on research, identify needs and provide solutions. This provides an aim for this study, to investigate the information access and social inclusion of children living with disabilities in a state in Nigeria.

\section{Summary of Literature Review}

The literature review has brought out some pertinent points in the study of disabled children. These points relate to legal provisions for their information access and social inclusion, the challenges they meet and the non-justiciable provision in Nigerian disability law; these are summarized below.

1) Legal Provisions for information access and social inclusion of disabled children: literatures reviewed showed that there are both international and indigenous provisions on the protection of disabled people. Conventions on the Elimination of All Forms of Discrimination Against Women (CEDAW), Universal Declaration on Human Rights (UDHR), African Charter on the Rights and Welfare of the Child (ACRWC) some of the international conventions that provide for information access and social inclusion of children living with disability. These conventions make government of each state responsible for its domestication and implementation in their states. The provisions of these conventions are domesticated in Discrimination against Persons with Disabilities (Prohibition) Act, 2018; Nigerian Child Rights Act, 2003; Ekiti State Rights of Person's with Disability Bill, 2013 and in many other state laws.

2) Information access: reviewed literature also showed that the disabled were being ignored as studies show that the required attention they needed was not being given. The necessary tools and amenities required for their access to information was documented yet no provision was made (Small, Myhill, \& Henrring-Harrington, 2015; Community Tool Box, 2019). The inclusion of non-justiciable provision in Nigeria's law as it regards to government's responsibility towards the disabled was found to contribute immensely to their lack of access to information as no one was made answerable for non-provision of their access tools; whereas provision of access tools is portrayed as requirement for exercise of human right in international conventions (Ajanwachukwu \& Philip, 2018).

3) Social inclusion of disabled children: the social inclusion of disable children was a main challenge as it was generally shown that they were not included in mainstream schools (Adetoro, 2014; Arimoro, 2019). Literature showed that the 
issue of their inclusiveness is not attached to placing them in special schools but allowing them to be included in mainstream schools (Tuersley-Dixon \& Frederickson, 2016). Disabled children who were included in mainstream schools were shown to be accepted because they were visible and not hidden.

4) Challenges met by disabled children: reviewed literature also showed that disabled children meet with a lot of challenges. Lack of funds channelled towards their access tools and educational materials was seen as a challenge as it makes them incapable of getting complete education and accessing information by themselves (Small, Myhill, \& Henrring-Harrington, 2015). The lack of love and lack of good treatments shown to disabled children by their family members was found not to support their education, access to information and social inclusion in the society. Their families were found to exhibit the behavior of hiding them from the public, thereby preventing them from attending schools; and they were also found not showing them love (Hayes, 2017; Koller, Pouesard, \& Rummens, 2017; World Bank, 2019). Other challenges shown in the reviewed literature were the fact that they were bullied, felt lonely and were normally excluded in the society; this was asserted to have the tendency of making them suffer psychologically. As a result, it was stated that the disabled would always be in need of counselling; thus a need for counselling unit in disability schools or mainstream schools.

\section{Methodology}

This study investigated the information access and social inclusion of children living with disabilities. A case study design was used for the study. The population consisted of 40 teachers of children living with disabilities in Ekiti State who gathered for a workshop. Due to the small number of the population, they were all used for the study. A qualitative method was used for this study using a self-designed structured interview. Instrument was distributed by hand to all 40 teachers; the instrument passed through face and content validity. Thematic content analysis was used to manually analyse the interview data, and codes were assigned to the data that has been categorized into different disability types. Constant comparative method of data analysis was also applied to compare and contrast codes; while data connections were made paying attention to categories of data and concepts. Respondents were assigned numbers to differentiate evidence from another; and evidences from respondents were conceptually categorized. Different evidences under each concept were also noted and placed under subsets. This continued until saturation was made, then evidences of research were selected from each concept and subset and tabulated, while the number of respondents with like evidences were noted.

\section{Results}

One research instrument was used to obtain data from 40 teachers in disability schools but only 29 copies were returned. Content analysis and report of find- 
ings for this study has been arranged under the categories: Access to information, challenges to information access and social inclusion of children living with disabilities. In response to each heading is a table divided into three groups of disability captured in this study; they are the physically disabled, the blind and the deaf. Evidence of findings is shown with explanations to each table.

\subsection{Ability to Access Information by Disabled Children}

In order to find out the ability to access information by the disabled children, they were placed in groups of the physically disabled, the blind and the deaf. The physically disabled were only 2, the blind were 19 and the deaf were 8 . Their responses are shown in Table 1 with evidences of result. This focuses on the materials they require for their learning and the ones available for their learning, the libraries available for their learning, their study method and their means of accessing information in their school environment. The letter " $R$ " has been used to represent respondent; while numbers attached behind the letter " $R$ " represent the specific respondent whose response is used as evidence of result. Numbers placed before the letter " $R$ " represent the total number of respondents whose evidences were used.

Table 1 revealed that physically disabled children have no difficulty in accessing information for their learning. This is because of the availability of movement aids like wheel chairs, crutches and ramps; with the inclusion of their teachers' assistance. It was however revealed that there was no availability of a library to support learning in the school environment and their supply of calliper was insufficient. This implies that the physically challenged are able to access information despite the unavailability of a library to support learning.

Table 1 also revealed that the blind disabled also require a lot of resources which are not sufficient in their school. Almost all the respondents stated that the state of their library was poor as there were faulty Braille machines and insufficient Braille sheets; there were also no furniture and no computers. They were found to access information by mobility training, through the use of cane guide, by listening to their radio and phone. This implies that the blind disabled have limitations in the resources they require to access information. Thus their access to information is limited and not complete.

It was also revealed that the deaf disabled require furniture and visual materials to access information and these materials are insufficient. Due to insufficient materials for hearing aid, their teachers guide them in accessing academic information. All the respondents agreed that there was no library while two respondents said they were located in integrated schools. This as well implies that there is limited access to information material by children living with disability as their dependence on their teachers as aid to information access bothers on their right to freedom of expression. It also implies that children in this study would not be able to carry out self-learning as their right to human dignity is continuously breached by their full dependence on their teachers. 
Table 1. Access to information by disabled children.

\begin{tabular}{|c|c|c|c|c|c|c|}
\hline Groups & $\begin{array}{l}\text { Item } 1 \\
\text { The materials required for } \\
\text { learning }\end{array}$ & $\begin{array}{l}\text { Item } 2 \\
\text { Materials available } \\
\text { for learning }\end{array}$ & $\begin{array}{l}\text { Item } 3 \\
\text { Availability of } \\
\text { libraries for } \\
\text { learning }\end{array}$ & $\begin{array}{l}\text { Item } 4 \\
\text { Study } \\
\text { assistance }\end{array}$ & $\begin{array}{l}\text { Item } 5 \\
\text { Means to access } \\
\text { information on school } \\
\text { environment }\end{array}$ & $\begin{array}{l}\text { Item } 6 \\
\text { Availability } \\
\text { of ramps }\end{array}$ \\
\hline $\begin{array}{l}\text { 1. Physically } \\
\text { disabled ( } 2 \\
\text { respondents) }\end{array}$ & $\begin{array}{l}\text { In response to this, both } \\
\text { respondents agreed that } \\
\text { calipers, textbooks, } \\
\text { wheelchairs were required for } \\
\text { their learning. For example: } \\
\text { R1: "Callipers, textbooks, } \\
\text { wheelchairs, pen etc." }\end{array}$ & $\begin{array}{l}\text { In response to this, it } \\
\text { was shown that the } \\
\text { materials required for } \\
\text { learning were } \\
\text { available except } \\
\text { calipers which were } \\
\text { few in number. For } \\
\text { instance: } \\
\text { R1: "textbooks, few } \\
\text { caliper and } \\
\text { wheelchairs" } \\
\text { R2: "textbooks" }\end{array}$ & $\begin{array}{l}\text { When they were } \\
\text { asked if libraries } \\
\text { were available, } \\
\text { the response was } \\
\text { on the negative. } \\
\text { For instance: } \\
\text { R1: "No" } \\
\text { R2: "No" }\end{array}$ & $\begin{array}{l}\text { In response to } \\
\text { assistance in } \\
\text { their studies, it } \\
\text { was shown that } \\
\text { they receive } \\
\text { assistance. For } \\
\text { instance: } \\
\text { R1: "Through } \\
\text { the aid of } \\
\text { teachers \& staff } \\
\text { members" } \\
\text { R2: "Through } \\
\text { the assistance of } \\
\text { their able child" }\end{array}$ & $\begin{array}{l}\text { In response to how they } \\
\text { move around to access } \\
\text { information in the school } \\
\text { environment, it was } \\
\text { shown that crutches and } \\
\text { the help of their able } \\
\text { teachers assist them in } \\
\text { learning. For instance: } \\
\text { R1: "By wheeling ... } \\
\text { crutches" } \\
\text { R2: "Supporting by able } \\
\text { staff" }\end{array}$ & $\begin{array}{l}\text { R1 \& R2: } \\
\text { "Yes" }\end{array}$ \\
\hline $\begin{array}{l}\text { 2. The blind } \\
\text { (19 } \\
\text { respondents) }\end{array}$ & $\begin{array}{l}\text { Braille machine (15Rs), Braille } \\
\text { sheet (10R), typing sheet } \\
\text { (10Rs), typewriter (11Rs) } \\
\text { computer system (10Rs), } \\
\text { Braille textbook (1R), tailor } \\
\text { frame ((1), abacus (1), talking } \\
\text { calculator (1), talking } \\
\text { wristwatch (1), chairs (1R), } \\
\text { Scanner (14Rs), tables (1R) } \\
\text { Landscaping of school } \\
\text { environment (1R), writing } \\
\text { frame (1R), Stilus (1R), } \\
\text { writing materials (1R), } \\
\text { mobility materials (1R), } \\
\text { Materials for teaching } \\
\text { mathematics (1R), recording } \\
\text { materials (1R) }\end{array}$ & $\begin{array}{l}\text { 19Rs: Writing frame } \\
\text { (11Rs), typewriters } \\
\text { (7Rs), braille sheet } \\
\text { (1R), braille machine } \\
\text { (6Rs), slate (1R), stilus } \\
\text { (7Rs), writing frame } \\
\text { (7Rs), faulty Braille } \\
\text { machine (5Rs), few } \\
\text { braille papers (5Rs) } \\
\text { 1R: "Braille sheet } \\
\text { (please note, they are } \\
\text { not enough" }\end{array}$ & $\begin{array}{l}\text { 14Rs: "Yes" } \\
1 \mathrm{R}: \text { "No" } \\
\text { On the state of } \\
\text { the library, the } \\
\text { following are the } \\
\text { responses: } \\
\text { "Sorry state" } \\
\text { (2Rs), "Very } \\
\text { poor"1R), "No } \\
\text { facilities e.g. } \\
\text { table, chair" } \\
\text { computer". } \\
\text { 10Rs stated that } \\
\text { there were no } \\
\text { facilities and ICT }\end{array}$ & $\begin{array}{l}\text { "By listening to } \\
\text { note given } \\
\text { (3Rs)", } \\
\text { 7Rs said they } \\
\text { study well: } \\
\text { "they study } \\
\text { very well". } \\
\text { "under the } \\
\text { supervision of } \\
\text { their teachers" } \\
\text { (4Rs) }\end{array}$ & $\begin{array}{l}\text { "Through orientation, } \\
\text { mobility training" (5Rs), } \\
\text { "Through mobility with } \\
\text { cane guide" (2Rs). } \\
\text { 5Rs stated that teachers } \\
\text { assist them to get } \\
\text { information on their } \\
\text { environment. 9Rs stated } \\
\text { that it is through mobility } \\
\text { training. } \\
\text { "... with cane guide, } \\
\text { sighted guide" (1R) } \\
\text { "By listening to radio \& } \\
\text { phone" (1R) }\end{array}$ & $\begin{array}{l}\text { 15Rs: “No" } \\
\text { 1R: "Yes" }\end{array}$ \\
\hline $\begin{array}{l}\text { 3. The deaf ( } 8 \\
\text { respondents) }\end{array}$ & $\begin{array}{l}\text { Computers (5Rs), more } \\
\text { vacation (2Rs), table (4rs), } \\
\text { Projectors ((2Rs), Internet } \\
\text { (1R), Personal teacher (2Rs), } \\
\text { chalk (4Rs), textbooks (4Rs), } \\
\text { hearing aids (2Rs), Financial } \\
\text { resource (2Rs) }\end{array}$ & $\begin{array}{l}\text { Table \& desk (2Rs), } \\
\text { Chairs (2Rs), books } \\
\text { (2Rs), textbooks } \\
\text { (2Rs), Few teachers } \\
\text { (2Rs). }\end{array}$ & $\begin{array}{l}\text { "No" (8Rs) } \\
\text { "Yes" (none) } \\
\text { On the state of } \\
\text { the library, the } \\
\text { following are the } \\
\text { responses: } \\
\text { "Poorly, none } \\
\text { availability of } \\
\text { resources" (2Rs) } \\
\text { "Only its located } \\
\text { in an integrated } \\
\text { school" (2Rs) }\end{array}$ & $\begin{array}{l}\text { "Teacher guide } \\
\text { them" (6Rs), } \\
\text { "They are } \\
\text { taught with } \\
\text { rudiment of } \\
\text { learning" ( } 2 \mathrm{Rs} \text { ) }\end{array}$ & $\begin{array}{l}\text { "Through their teachers" } \\
\text { (4Rs), "Poorly" (2Rs) }\end{array}$ & $\begin{array}{l}\text { All } 8 \text { Rs said } \\
\text { there were } \\
\text { no ramps. } \\
\text { They walk: } \\
\text { "Some walk } \\
\text { by } \\
\text { themselves" } \\
\text { (6Rs) }\end{array}$ \\
\hline
\end{tabular}

The results from Table 1 also imply that disabled schools depend wholly on government and philanthropist for provision of disability materials. It further shows that majority of the students are from poor homes and would not be able to access needed information where they are not provided disability aid materials; as a result, their access to information would always be limited. 


\subsection{Challenges Children Living with Disability Face in Accessing Information}

In order to find out the challenges faced by disabled children, they were placed in groups of the physically disabled, the blind and the deaf. The physically disabled are 2 in number, the blind are 19 in number and deaf are 8 in number. The letter " $R$ " has been used to represent respondents; while numbers attached to them represent the specific respondent whose evidence is used for emphasis.

Table 2 revealed that disabled children were placed in categories of: the physically disabled, the blind and the deaf. It was revealed that physically disabled children have challenges in managing the few and insufficient teaching materials they have. They also have insufficient teachers; they lack walking aids and callipers and as a result, they find it challenging to access their classrooms. It was also revealed that their challenges were being met by the assistance of their state government, philanthropist and the parents of the students. This implies that physically disabled children have limitations in their information access and thus a major challenge in their education. There is also the implication that their education is slowed down due to insufficient supplies of teaching, learning aids and mobility aids; plus insufficient teachers. There is also the implication that teachers of the disabled would be handling large workloads and would be excessively burdened in taking care of disabled children. This is as a result of their insufficient number including their use as mobility aids. More implication also show that majority of the disabled children are from poor homes and rely much on government and philanthropist.

It was also revealed that the blind disabled face challenges in accessing academic information as their visual tools and special educational materials are

Table 2. Challenges to information access.

\begin{tabular}{|c|c|c|}
\hline Groups & Challenges & How challenges are met \\
\hline $\begin{array}{l}\text { 1. Physical disability: } \\
2 \text { Respondents (2Rs) }\end{array}$ & $\begin{array}{l}\text { 2Rs stated they have challenges with teaching materials, } \\
\text { walking aids, calipers and with number of teachers. They } \\
\text { also stated that they have challenges with accessing their } \\
\text { classrooms: R1: "inaccessibility of classroom" }\end{array}$ & $\begin{array}{l}\text { Their challenges are been met through the assistance of the } \\
\text { state government and philanthropist, for example: } \\
\text { R1: "Through government and philanthropist..." } \\
\text { R2: Through government initiative" }\end{array}$ \\
\hline
\end{tabular}

2. The Blind: 19

Respondents (19Rs) The 19Rs stated that their challenges are on the areas of their Their challenges are been handled partially. They are been met visual impairment and special educational resources needed by the assistance of the state government, the students' to access information. Example: R13: "Provision of instructional materials for their education" parents and by the disabled ability to learn mobility skills and use of Braille. Examples:

R1: "Through the government"

R2: "It is been provided by the parents, government"

R4: "They are introduced to Braille reading, typing, and mobility skills"

3. Deaf: 8 8Rs stated that their challenges are in the areas of

Respondents (8Rs) educational materials especially English language and

Mathematics. Examples: R3: "More textbooks, likely English

language, Mathematics etc.". R4: "More textbooks, likely

mathematics, biology, English language...” R1: "Educational

and learning experience"
When asked on how the needs have been met, these were their responses:

Rs1 - 4: "Partially addressed"; Rs5 \& 6: "Some have not

received" 
insufficient. These needs were shown to be met partially by the parents of the students and by their state government. It was also revealed that the students receive training on mobility and Braille reading. The teaching on mobility and braille reading provides the implication that they are being provided with aid to access information; while the insufficient supplies of visual and educational materials provides the implication that they have limitation in accessing academic information. More implication also shows that there is much reliance on the state government for visual and educational aids.

It was further revealed that the deaf also have challenges in the area of educational materials especially English language and mathematics. They do not have adequate educational materials and so have limited access to information. This implies that they take longer time to study and have limitation in their access to information.

\subsection{Social Inclusion of Disabled Children in the Society}

In order to find out the social inclusion of disabled children, they were placed in groups of the physically disabled, the blind and the deaf. The physically disabled are 2 in number, the blind are 19 in number and deaf are 8 in number. The letter " $R$ " has been used to represent respondents; while numbers attached to them represent the specific respondent whose evidence is used for emphasis.

Table 3 revealed that disabled children are socially included in their special schools as they are made to interact with one another in school activities; however they are not in integrated schools and so has no social inclusion there. The physically disabled, the deaf and the blind all showed that there is good relationship among the disabled and between the disabled and the able. Bullying was only minimally evident among the blind and deaf. Among 14 respondents, only one among the blind agreed on presence of bullying among the disabled. All the respondents in all the three groups of disability agreed that disabled children receive poor treatment from their family members. It was also revealed that there were no counseling units among the blind and deaf. The implications of this show that disabled children are not receiving love from homes and so have the tendency to exhibit psychological issues; and there is no counseling unit to take care of such issues. This also implies that disability schools in Nigeria are seen as a place of succor by the disabled children. More implication shows that there is a need to provide counseling units for the disabled children or alternatively hold counseling sessions for them. There is also an implication that counseling session should periodically be arranged for families of disabled children.

\section{Discussion of findings}

The major findings of this study show that:

1) In terms of ability to access information, the physically disabled have mobility aid tools and they are also assisted by their teachers due to insufficient mobility tools. They have insufficient materials like callipers and there is no 
Table 3. The social inclusion of children living with disability.

\begin{tabular}{|c|c|c|c|c|c|c|}
\hline Groups & $\begin{array}{l}\text { Item } 1 \\
\text { Relationship behavior of } \\
\text { children }\end{array}$ & $\begin{array}{l}\text { Item } 2 \\
\text { Treatment by } \\
\text { family }\end{array}$ & $\begin{array}{l}\text { Item } 3 \\
\text { Inclusion in school } \\
\text { activities }\end{array}$ & $\begin{array}{l}\text { Item } 4 \\
\text { Relationship } \\
\text { with the able } \\
\text { children }\end{array}$ & $\begin{array}{l}\text { Item } 5 \\
\text { Level of } \\
\text { acceptance by } \\
\text { able children: } \\
100 \%\end{array}$ & $\begin{array}{l}\text { Item } 6 \\
\text { Counseling unit }\end{array}$ \\
\hline $\begin{array}{l}\text { 1. Physical } \\
\text { disability: } 2 \\
\text { Respondents } \\
\text { (2Rs) }\end{array}$ & $\begin{array}{l}\text { When asked on their } \\
\text { relationship behavior, it was } \\
\text { stated that they were well } \\
\text { behaved. For example: } \\
\text { R1 \& R2: "well behaved" } \\
\text { When asked on whether they } \\
\text { are bullied, the response was } \\
\text { negative: "No" } \\
\text { When asked whether they feel } \\
\text { lonely, the response was } \\
\text { negative: "No" }\end{array}$ & $\begin{array}{l}\text { When asked if there } \\
\text { are complaints of } \\
\text { poor treatments } \\
\text { from family, the } \\
\text { response was on } \\
\text { affirmative, for } \\
\text { example: } \\
\text { R1 \& R2: "Yes" }\end{array}$ & $\begin{array}{l}\text { When asked } \\
\text { whether they were } \\
\text { included in school } \\
\text { activities, the } \\
\text { response was } \\
\text { positive. For } \\
\text { example: } \\
\text { R1: "Through social } \\
\text { gathering in } \\
\text { school". } \\
\text { R2: "Through } \\
\text { cleared } \\
\text { environment" }\end{array}$ & $\begin{array}{l}\text { When asked if } \\
\text { they relate well } \\
\text { with able } \\
\text { children, both } \\
\text { responded in the } \\
\text { affirmative }\end{array}$ & $\begin{array}{l}\text { When asked to } \\
\text { rate their level of } \\
\text { acceptance by } \\
\text { able children, the } \\
\text { evidence was } \\
60 \% \text {. For } \\
\text { example: } \\
\text { R1 \& R2: } 60 \%\end{array}$ & $\begin{array}{l}\text { When asked on } \\
\text { the availability of } \\
\text { counseling unit, } \\
\text { they responded } \\
\text { in the } \\
\text { affirmative. } \\
\text { Examples: } \\
\text { R1 \& R2: "Yes" }\end{array}$ \\
\hline $\begin{array}{l}\text { 2. The Blind: } \\
19 \\
\text { Respondents } \\
\text { (19Rs) }\end{array}$ & $\begin{array}{l}\text { When asked on their } \\
\text { relationship behavior, 14Rs all } \\
\text { said that they are very friendly. } \\
\text { Example: } \\
\text { R7: "They accommodate, } \\
\text { interact, very friendly with } \\
\text { those close" } \\
\text { When asked whether they feel } \\
\text { lonely, the response among } \\
\text { majority of them (14Rs) was } \\
\text { positive. Example: } \\
\text { R1: "Yes, when nobody relate } \\
\text { with them." } \\
\text { When asked on whether they } \\
\text { are bullied, majority responded } \\
\text { negatively. For example: } 14 \text { Rs: } \\
\text { "No" } \\
\text { However } 1 \text { respondent said yes: } \\
\text { 1R: "Yes ...It brings inferiority } \\
\text { to the children" }\end{array}$ & $\begin{array}{l}\text { When asked if there } \\
\text { are complaints of } \\
\text { poor treatments } \\
\text { from family, the } \\
\text { response was } \\
\text { affirmative: } \\
\text { Example: } \\
\text { 15Rs: "Yes" }\end{array}$ & $\begin{array}{l}\text { 14Rs said they are } \\
\text { included in school } \\
\text { activities. Example: } \\
\text { R3: "By } \\
\text { participating in } \\
\text { quiz and social } \\
\text { activities" } \\
\text { R4: "By } \\
\text { participating in } \\
\text { social gathering" }\end{array}$ & $\begin{array}{l}\text { When asked if } \\
\text { they relate well } \\
\text { with able } \\
\text { children, 15Rs } \\
\text { were on the } \\
\text { affirmative. } \\
\text { Example: } \\
\text { 15Rs: "Yes" }\end{array}$ & $\begin{array}{l}8 \text { Rs: } 50 \% \\
\text { 5Rs: } 60 \% \\
\text { 2Rs: } 80 \%\end{array}$ & $\begin{array}{l}\text { When asked on } \\
\text { the availability of } \\
\text { counseling unit, } \\
\text { the responses } \\
\text { were as follows: } \\
\text { 12Rs: "No" } \\
\text { 3Rs: "Yes" } \\
\text { When asked } \\
\text { what they } \\
\text { thought about a } \\
\text { need for one, } \\
\text { their responses } \\
\text { were as follows: } \\
\text { 3Rs: Yes } \\
\text { 12Rs: No }\end{array}$ \\
\hline $\begin{array}{l}\text { 3. Deaf: } 8 \\
\text { Respondents } \\
\text { (8Rs) }\end{array}$ & $\begin{array}{l}\text { When asked if they were of } \\
\text { good behavior, all } 8 \text { Rs said they } \\
\text { are of good behavior. } \\
\text { When asked if they feel lonely, } \\
\text { Rs said: "No", however } 2 \text { Rs } \\
\text { said sometimes, for example: } \\
\text { "Sometimes" } \\
\text { When asked if they are bullied, } \\
\text { 2Rs said yes, for example: } \\
\text { "Sometimes ...children natural } \\
\text { way... } \\
\text { However } 4 \text { respondents } \\
\text { disagreed. For example: } \\
\text { 4Rs: "Nill" }\end{array}$ & $\begin{array}{l}\text { When asked if there } \\
\text { are complaints of } \\
\text { poor treatments } \\
\text { from family, all 8Rs } \\
\text { were affirmative: } \\
\text { Example: } \\
\text { R3: "Maltreatment" } \\
\text { R7::Marginalized } \\
\text { and stigmatized" }\end{array}$ & $\begin{array}{l}\text { All } 8 \text { Rs said they } \\
\text { are included in } \\
\text { activities. Example: } \\
\text { R5: "By educate } \\
\text { them and activities } \\
\text { participation". }\end{array}$ & $\begin{array}{l}\text { When asked if } \\
\text { they relate well } \\
\text { with able } \\
\text { children, all 8Rs } \\
\text { were affirmative. } \\
\text { Example: } \\
\text { 8Rs: "Yes" }\end{array}$ & $\begin{array}{l}\text { 3Rs: } 50 \% \\
\text { 1R: } 75 \% \\
\text { 1Rs: } 70 \% \\
\text { 2Rs: } 20 \% \\
\text { 1R: } 60 \%\end{array}$ & $\begin{array}{l}\text { When asked on } \\
\text { the availability of } \\
\text { counseling unit, } \\
\text { the responses } \\
\text { were as follows: } \\
\text { 8Rs: "No" } \\
\text { 4Rs said there is } \\
\text { need for one. }\end{array}$ \\
\hline
\end{tabular}


library to aid learning. The blind disabled have mobility aid tools like cane guides and their mobility training also assist them. They also access information by listening to radio, and use of phone. They have insufficient materials needed for their learning; materials like Braille machines, Braille sheets, computers and furniture (tables and chairs) and their state of the library was poor. The Deaf disabled have insufficient furniture and visual materials; they do not have any library. They were also found to be generally from poor homes and depend on governments and philanthropist for funding.

2) In terms of challenges met by the disabled, the physically disabled have challenges in the area of teaching materials which are insufficient. They also have insufficient teachers, and lack callipers and walking aids. As a result, they find it challenging to access their classrooms. These challenges are met by their state government, their parents and philanthropist. The blind have challenges in area of visual aids and special educational materials. Their challenges are met by their state government, their parents and a special training they receive on mobility. The deaf have challenges in academic materials which are insufficient; especially materials like English and Mathematics.

3) In terms of their social inclusion, all the disabled categories are socially included in their special schools; however since they are not in integrated or mainstream schools, they are not socially included there. There is no bullying among the physically challenged while there is minimal bullying among the deaf and the blind. They were found not to be generally treated well at their homes. It was also found that there was no counselling unit among the blind and the deaf.

This study has provided results on the information access and social inclusion of children living with disabilities in Ekiti State. The results of this study showed that children with disabilities in the three disability groups studied have insufficient materials for education, information access and mobility. It was also found that they do not have libraries and sufficient teachers. Due to inadequate resources needed for mobility, most of them especially the blind and physically challenged depended on the teachers and friends for mobility. This clearly deviates from the provisions of ACWRC and CRC (Ajanwachuku \& Philip, 2018) which states that every child shall enjoy the rights and freedom guaranteed in the charter irrespective of his or her fortune or other status (Art.3, ACRWC). It also goes against the provisions of Discrimination against Persons with Disabilities (Prohibition) Law (2020). Although more results from the study showed that the government provides aid in relation to resource availability; however they were found not to be sufficient. As a result, parents of the students and other people provide resources they need on charity basis. This reiterates the conclusions in Community Tool Box (2019), and Kaeding, Velasquez and Price (2017) which found that there were insufficient tools needed for access by disabled children because studies have not focused more on what they need for access but on studying their inabilities. This study has therefore covered this gap and provided an addition to knowledge by showing what different categories of disabled 
children need for information access and social inclusion. It also underpins the theory of social model on disability which states that the society did not provide tools and facilities needed for the enablement of the disabled but focuses on their disability and not on the ability to be able.

The non-provision of libraries as shown in the result of this study and the fact that some of the respondents do not think they require libraries, confirm the conclusion of World Bank (2019) that children living with disabilities are being left behind in the global effort to improve education and access to information. The result of this study which showed that parents of disabled children are maltreating them reiterates the findings in Hayes (2017) where it was shown that most parents denied their children access to education because they did not want them to be seen; in order to avoid embarrassment. In this study, results showed that they do not stop them from attending schools but maltreat them and deny them affection and love; which invariably reduces their confidence. The result of this study showing that disabled children do not get love and support from their family and as well do not have counselling unit in their schools reflects the conclusion in Koller, Pouesard and Rummens (2017) that they will have psychological issues. Koller, Pouesard and Rummens (2017) found that children with disabilities suffer from bullying, loneliness and exclusion with the tendency to suffer psychologically; making them always in need of counselling. More so, the results of the study which shows that disabled children are in their separate schools reiterates the conclusion of Arimoro (2019) and Adetoro (2014) that Nigerian school system places disabled children in separate schools away from the able children, and deny them of social inclusion in mainstream schools.

\section{Conclusion}

Children with disabilities are just like other able children, but with special nature; thus their equal rights to living with all attendant requirements should not be denied. It is one thing to provide for fundamental human rights, and disability laws but it is another thing to ensure that everyone especially children has the ability to exercise those rights equally. Where a population, majority of who are poor; do not have the means to access information or get socially included because they do not have disability tools, then they are already been marginalized and cut off gradually from society. There should be concerted efforts made to ensure that this group of people who can easily be forgotten gets involved in every activity taking place in the society. There should also be arrangements made to ensure that parents of the disabled appreciate the special nature of their children.

\section{Recommendation}

In light of the findings in this study, it is recommended that the government of Ekiti State, Nigeria should ensure that the needs of disabled children are documented in order to ensure that needed provisions are channelled towards meet- 
ing their needs in sufficient measures. More so, there should be adequate plan to set aside funds for support of disability schools and disabled children.

The Ekiti State Ministry of Education should also ensure that libraries are built and equipped for children living with disabilities. They should also ensure that there is arrangement for counselling units in disability schools or counselling sessions with disabled children is included in their education.

Non-Governmental organizations (NGOs) especially Federation of International Women Lawyers (FIDA) Ekiti State, should ensure that families of disabled children are sensitized on the need to accept and show them love in order to enhance their total wellbeing.

\section{Conflicts of Interest}

The authors declare no conflicts of interest regarding the publication of this paper.

\section{References}

Abang, T. B. (2007). Disablement, Disability and Nigeria's. Disability, Handicap and Society, 3, 71-77. https://doi.org/10.1080/02674648866780061

Adetoro, R. A. (2014). Inclusive Education in Nigeria, a Myth or Reality? Creative Education, 5, 1777. https://scholar.google.com https://doi.org/10.4236/ce.2014.520198

African Charter on the Rights and Welfare of the Child (ACRWC) (1990). Charter on the Rights and Welfare of the Child. https://www.achpr.org

Ajanwachuku, M. A., \& Philip, H. F. (2018). The Nigerian Child's Rights Act and the Rights of Children with Disabilities: What Hope for Enforcement? Currental Juridic, 72, 57-66. https://www.researchgate.net

Arimoro, A. E. (2019). Are They Not Nigerians? The Obligation of the State to End Discriminatory Practices against Persons with Disabilities. International Journal of Discrimination and the Law, 19, 89-109. https://doi.org/10.1177/1358229119846764

Benstead, H. (2019). Exploring the Relationship between Social Inclusion Special Educational Needs: Mainstream Primary Perspectives. Support for Learning, 34, 34-53.

https://onlinelibrary.wiley.com https://doi.org/10.1111/1467-9604.12234

Buckland, M. K. (1991). Information as Thing. https://assitdl.onlinelibrary.wiley.com

Community Tool Box (2019). Section 4: Ensuring Access for People with Disabilities. https://ctb.ku.edu

Convention on the Elimination of All Forms of Discrimination against Women (1971). https://www.un.org

Definitions.Net (2019). Information Access, What Does Information Access Mean? https://www.definition.net

Discrimination against Persons with Disabilities (Prohibition) Act (2018). Nigerian Health Watch.

https:///nigeriahealthwatch.com/wp-content/uploads/bsk-pdf-manager/2019/02/1244Discrimination-Against-Persons-with-Disabilities-Prohibition-ACT-2018.pdf

Discrimination against Persons with Disabilities (Prohibition) Law (2020). A Law to Pro- 
hibit Discrimination against Persons with Disabilities and Other Related Matters, No. 3. Ekiti State of Nigeria. https://ekitistate.gov.ng/hoa/2020/No3of2020.pdf

Encyclopedia (2020). Information Access. https://www.encyclopedia.com

European Disability Forum (2016). Children's Day 2016: The Voices of Children with Disabilities.

https://www.edf-feph.org/Childrens-day-2016-the-voices-of-children-with-disabilitiesshould-be-heard/

Furrer, C., \& Skinner, E. (2003). Self Determination Theory.

https://www.selfdeterminationtheory.org

Hayes, K. (2017). Education Access for Children with Disabilities in Ghana. https://borgenproject.org

International Justice Resource Center (2019). United Nations and Regional Human Rights. https://ijrcenter.org/2019/01/02/january-2019-united-nations-and-regional-human-rig hts-bodies-in-session/

Kaeding, J., Velasquez, D. L., \& Price, D. (2017). Public Libraries and Access for Children with Disabilities and Their Families: A Proposed Inclusive Library Model. Journal of the Australian Library and Information Association, 66, 96-115. https://doi.org/10.1080/24750158.2017.1298399

Kazeem, Y. (2018). Nigeria Has Become the Poverty Capital of the World. Quartz Africa. https://www.qz.com/africa/1313380/nigerias-has-the-highest-rate-of-extreme-povertyglobally

Koller, D., Pouesard, M. L., \& Rummens, J. A. (2017). Defining Social Inclusion for Children with Disability: A Critical Literature Review. Children and Society, 32, 1-13. https://doi.org/10.1111/chso.12223

Lloyd, A., Suzanne, L., \& Kennan, M. A. (2017). On Becoming Citizens: Examining Social Inclusion from an Information Perspective. Australian Academic \& Research Libraries, 47, 304-315. https://doi.org/10.1080/00048623.2016.1256806

Manzoor, M., \& Vimarlund, V. (2018). Digital Technologies for Social Inclusion of Individuals with Disabilities. Health and Technology, 8, 377-390. https://link.springer.com https://doi.org/10.1007/s12553-018-0239-1

Ministry of Justice Ekiti State (2020). Discrimination against Persons with Disabilities. https://www.ekitistate.gov.ng

Mitra, S., \& Groce, N. (2017). Extra Cost of Living with Disability: A Review and Agenda for Research. Disability and Health Journal, 10, 475-484.

https://doi.org/10.1016/j.dhjo.2017.04.007

Nigerian Child Rights Act (2003). Laws of the Federation of Nigeria. https://www.refworld.org

Nigerian Constitution (1999). Chapter Four of the 1999 Constitution of Nigeria. https://www.waado.org/nigerdelta/constitutionmatter/1999constitution/chapterfour.ht $\underline{\mathrm{ml}}$

Rabinowitz, N. (2020). Tash Conference Virtual Edition. SCHED. https://2020tashconference.sched.com/nicolerabinowitz

SCOPE (2021). Social Model of Disability. SCOPE-Equality for Disabled People. https://www.scope.org.uk/about-us/social-model-of-disability-theory

Small, R. V., Myhill, W. N., \& Herring-Harrington, L. (2015). Developing Accessible Libraries and Inclusive Libraries in the 21st Century: Examples from Practice. In Accessibility for Persons with Disabilities and the Inclusive Future of Libraries (Advances in Librarianship) (Vol. 40, pp. 73-88). Emerald Group Publishing Limited. 
https://doi.org/10.1108/S0065-283020150000040013

Tuersley-Dixon, L., \& Frederickson, N. (2016). Social Inclusion of Children with Complex Needs in Mainstream: Documents Visibility and Severity of Disability Matter? International Journal of Developmental Disabilities, 62, 89-97.

https://doi.org/10.1179/2047387715Y.0000000011

UNICEF (2019). State Party Reports. https://www.unicef-irc.org

Universal Declaration on Human Rights (1948). Universal Declaration Human Rights at 70. https://www.ohchr.org

World Bank (2019). Education: Children with Disabilities Are Being Left behind Says World Bank GPE Report. Press Release No. 2018/08/Education.

World Bank (2020). Social Inclusion. https://www.worldbank.org

World Health Organization (WHO) (2019). Disabilities.

https://www.afro.who.int/health-topics/disabilities 